\title{
Effects of Cement Dust on Chlorophyll and Metabolism Products
}

\author{
Murat Tolga YILMAZ \\ Atatürk University, Engineering Faculty, Department of Environmental Engineering, Erzurum, TURKEY \\ mtyilmaz@atauni.edu.tr
}

Received Date: 09.03.2018

Accepted Date: 05.10 .2018

\begin{abstract}
Aim of study: Due to recent developments in the world, various industrial establishments began to operate without the pressures they create on the environment being taken into account. Some of these businesses are established on agricultural lands or on natural meadows and pasture areas. This study investigated the effects of dust particles, one of airborne contaminants, on some plant species.

Area of study: The changes in protein, total chlorophyll, carbohydrate and dry matter amounts of plant samples collected from the near and far periphery of a cement plant were investigated.

Material and Methods: Elm (Ulmus glabra), maple (Acer negundo) and yellow pine (Pinus sylvestris) plants were included in the study.

Main results: Cement dust emissions spreading in the environment had adverse effects on plant development. Significant reductions were observed for chlorophyll $(p<0.01)$, carbohydrates $(p<0.01)$, dry matter in leaves $(p<0.01)$ and dry matter in trunks $(p<0.005)$, as well as protein levels in pine $(\mathrm{p}<0.01)$ and elm $(\mathrm{p}<0.005)$.

Highlights: It was found that dust emissions clogged the pores in plant leaf tissue, negatively affecting photosynthesis and consequently causing a decrease in the levels of metabolic products.
\end{abstract}

Keywords: Cement dust, total chlorophyll, protein, dry matter, total carbohydrate

\section{Çimento Tozlarının Klorofil ve Metabolizma Ürünlerine Etkileri}

$\ddot{\mathbf{O} z}$

Çalışmanın amacı: Dünyada gelişmeye bağlı olarak çeşitli sanayi kuruluşları işletmeye açılmıştır. İşletmelerin bir kısmı tarım arazileri ya da doğal çayır ve meralar üzerine kurulmuştur. Bu çalışmada, hava kökenli kirletici parametrelerden olan toz partiküllerin bazı bitkiler üzerine etkisi incelenmiştir.

Çalı̧̧ma alanı: Çimento Fabrikası'nın yakın ve uzak çevresinden toplanan bitki örneklerinin protein, toplam klorofil, karbonhidrat ve kuru madde miktarlarının nasıl ve hangi yönde değiştiği araştırılmıştır.

Materyal ve Yöntem: Karaağaç (Ulmus glabra), akçaağaç (Acer negundo) ve sarıçam (Pinus sylvestris) bitkileri incelenmeye alınmıştır.

Sonuçlar: İstatistiki olarak, sırasıyla klorofil ve karbonhidrat miktarı açısından önemli anlamı taşıyan $\mathrm{p}<0.01$, kuru madde miktarı için ise yapraklarda önem seviyesi açısından $\mathrm{p}<0.01$ ve gövdelerde bu sonuç oldukça önemli olan $\mathrm{p}<0.005$ olarak azalma bulunmuştur. Protein açısından çamda $\mathrm{p}<0.01$ ve karaağaçta ise $\mathrm{p}<0.005$ olarak azalma tespit edilmiştir

Önemli Vurgular: Toz emisyonlarının özellikle bitki yaprak dokusundaki gözenekleri tıkayarak fotosentezi olumsuz etkilediği ve buna bağlı olarak metabolik ürünlerin düzeylerinde azalmalara neden olduğu saptanmıştır.

Anahtar kelimeler: Çimento tozu, toplam klorofil, protein, kuru madde, toplam karbonhidrat 


\section{Introduction}

Plants, which form the basis of the relationship between energy and matter in ecosystems, are faced with dangers of air, soil and water pollution, as well as drought. For this reason, distorted soil structure, mineral insufficiency, extreme temperatures, high light intensity and irresponsible soil management cause severe destruction in the nature (Kadığlu, 2004; Turfan, Savac1 \& Sarıyıldız, 2016). Physical-chemical properties and water holding capacity of soil, amount of oxygen, $\mathrm{pH}$, mineral content, and fading point are some of the parameters which can tell us what type of plants can grow in a certain environment. Environmental factors, however, are also important for development of plants (Berges L, Chevalier, Dumas, Franc \& Gilbert, 2005; Sarıyıldız and Küçük, 2009; Sağlam and Elvan, 2017). In Turkey, especially since 1970s, the terms "environmental issues" and "environmental pollution" have become frequently encountered and highly spoken terms in everyday life. It is recommended that necessary precautions to solve environmental problems or prevent environmental pollution should start primarily in the sources of pollution. Therefore, discharge of any waste into the environment should have a composition that is the least harmful for the nature (Öner, Ayan, Sivacioğlu \& İmal, 2007). Solid cement dusts affect the quality of air negatively. The source of these particles, which are air pollutants and harmful to vegetation, are mainly cement factories, but these also include power plants, stone crushing quarries, agricultural operations, iron and steel production and forest products facilities (Vandergrift et al., 1971). Dust and other gaseous pollutants in various sizes that are formed during cement production are significant air pollutants. Cement dust, creating air pollution, is non-toxic, nonflammable and non-explosive, and does not seriously harm human health. However, pollutants accumulate in the "alveoli" region of the lungs. This is because there are no hairs called "flickering hairs" in this region that are used to filter and remove particles. Particles smaller than 0.1 microns in size travel to the air bags of the lungs due to the Brownian motion and settle in the "alveoli". In general, particles larger than 1 micron are retained before reaching this region (Karpuzcu, 1988). Since cement factories are often located far from large settlements, they have a negative impact on rural areas in particular (Anonymous, 1983). Additionally, these dusts spread over a wide area under the influence of atmospheric conditions, accumulating on surrounding plants and preventing their normal development (Brandt and Rhoades 1973; Cireli, 1975; Katırcıŏlu and Iren 1988; Bayhan, 2016) affecting floristic composition (Brandt and Rhoades 1972; Sheikh, Öztürk \& Vardar, 1976), as well as altering the chemical structure of soil (Brands and Rhoades, 1973; Sheikh et al., 1976; Voran, 1984; Bayhan et al., 2002) and negatively affecting microbial species and activity (Lux, 1974; Bilen, 2010). In order to determine these adverse effects, chlorosis, leaf and branch drying or even complete drying were observed in Pinus sylvestris trees in Germany (Lux, 1974) and Ouercus trees in the United States (Rhoads, 1976). It was found that the lateral growth of the four selected species of forest vegetation in southwestern Virginia was adversely affected (Brandt and Rhoades, 1973). Lafraguta, Garcia-Criado, Arranz \& Vazquez-de-Aldana (2014), on the other hand, found that cement dust solution had a negative effect on the germination of alfalfa (Medicago sativa), which is a feed crop plant. The effects of cement dust on olive trees near Bornova in İzmir, Turkey were investigated by Sheikh et al. (1976), indicating the harmful effects on growth and development. Additionally, changes in wheat beans, apples and landscape plants were investigated by cement dust applications in different time periods and quantities in controlled environments (Singh and Rao 1981; Katırcıoğlu and Iren, 1988; Çetin, 2016).

This study investigated the effects of dust particles emitted from cement factories on chlorophyll a, chlorophyll b, total chlorophyll, carbohydrate, dry matter and dissolved protein quantities of plants. 


\section{Material and Methods \\ Material}

The pre-revised periphery of Aşkale Cement Factory in the northeastern part of the district of Asskale in the province of Erzurum, Turkey was selected as the study area. In this study, five separate samples were collected for each tree species from near the cement plant (at about $100 \mathrm{~m}$.) and from further points where pollution was less visible (at about $500 \mathrm{~m}$.). The collection and preservation processes of the elm (Ulmus glabra), maple (Acer negundo) and yellow pine (Pinus sylvestris) specimens obtained for the purpose of investigation were made according to the method by Kaçar (1972). The chemicals that were used in the study were of analytical purity.

\section{Method}

For the analysis of chlorophyll a and chlorophyll b, the plant samples were initially washed under tap water, and prepared for processing. Analyses were performed on five different specimens for each plant species. These procedures were carried out for both leaf and trunk samples. The plant specimens were weighed after they were dried, then left in an $80{ }^{\circ} \mathrm{C}$ incubator until they reached constant weight, and their dry matter quantities were determined (Singh and Rao, 1981). Chlorophyll a and chlorophyll $b$ analyses were performed to determine the amount of chlorophyll in fresh leaf tissues. For this purpose, fresh leaf tissues were weighed and crushed in $20 \mathrm{ml}$ of $80 \%$ acetone (Acetone:Water, 4:1, V/V). The same method was applied for each sample. The resulting mixture was filtered and centrifuged at $3000 \mathrm{rpm}$ for 15 minutes. The optical density of the chlorophyll extract was determined by a computerized colorimeter (Shimadzu, UV-160 A, UVSpectrophotometer) which could be adjusted to 645 and 663 nanometer wave lengths. Chlorophyll $\mathrm{a}$ and $\mathrm{b}$ amounts were determined as $\mathrm{mg} / \mathrm{g}$ in fresh leaves. By adding the amounts of chlorophyll $\mathrm{a}$ and $\mathrm{b}$ in our experiment, the total amount of chlorophyll in $1 \mathrm{~g}$ of fresh leaf tissue was determined by the following formulas (Sing \& Rao, 1981).

Chlorophyll a $=\frac{1,23 \times D_{663}-0,86 \times D_{645}}{\mathrm{~d} \times 1000 \times \mathrm{W}} \times V$

Chlorophyll $\mathrm{b}=\frac{1,93 \times D_{645}-3,6 \times D_{663}}{\mathrm{~d} \times 1000 \times \mathrm{W}} \times V$

W: Weight of fresh leaf;

V: Volume of acetone used;

D: Absorbance value

The values were found as $\mathrm{mg}$ chlorophyll/g fresh leaves.

The Norris and Ribbons (1971) phenolicsulfur method was used to determine the amount of carbohydrate in leaf tissue. The spectrophotometer was calibrated with standard solutions to 488 nanometers for hexoses and 480 nanometers for pentoses, and the standard curves in Figures 1 and 2 were obtained, respectively. With this method, hexose and pentose levels in the tissue were determined spectrophotometrically. Based on the findings, plant samples that were affected and not affected by cement dust were compared among themselves. The results were statistically analyzed by t-test. Evaluations were made according to the method by Düzgüneş (1963) and significant changes were identified. 


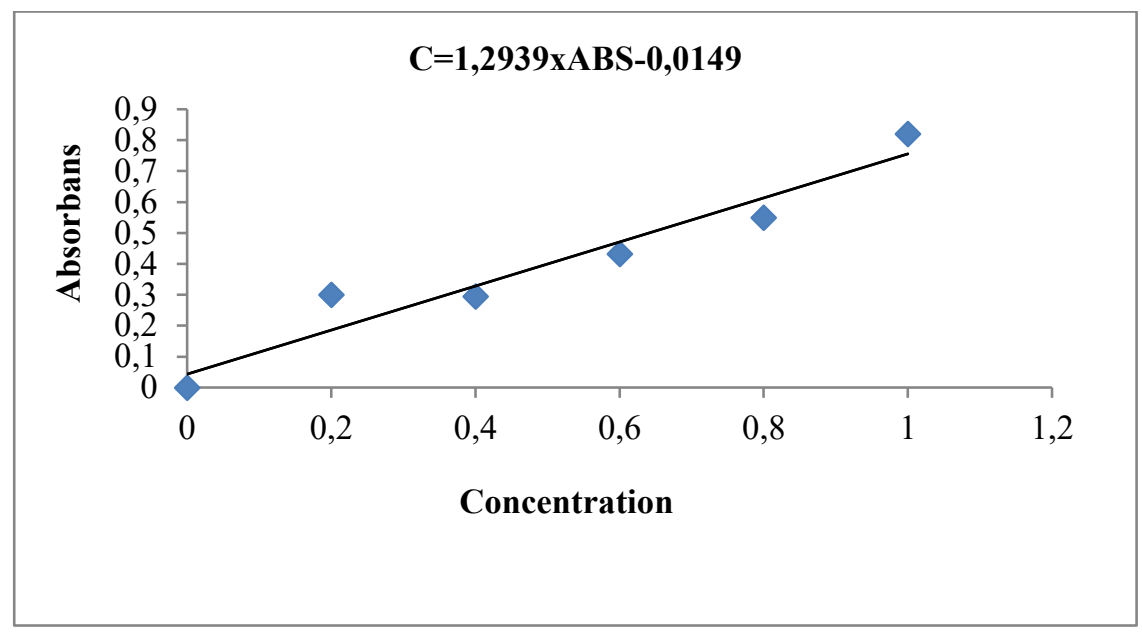

Figure 1.UV standard curve for hexose sugar, $(488 \mathrm{~nm})$

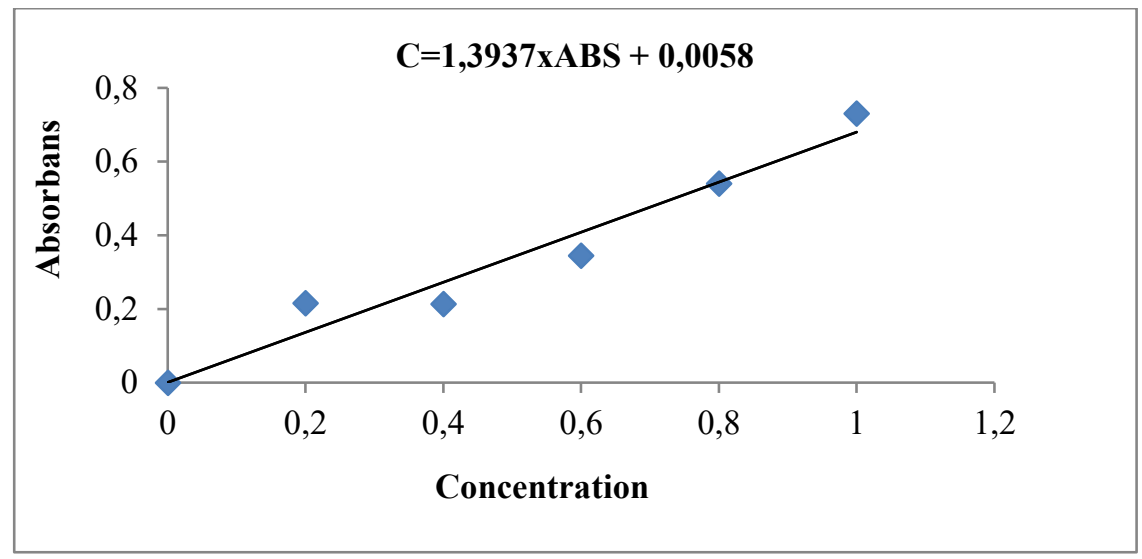

Figure 2.UV standard curve for pentose sugar, $(480 \mathrm{~nm})$

To determine the protein amounts, chlorophyll-removed leaves were crushed in a $0.05 \mathrm{M}$ phosphate buffer solution and the resulting liquid was filtered, transferred to tubes, and centrifuged. Protein amount was measured spectrophotometrically. The device was calibrated using standard protein solutions (Bradford, 1976). The standard curve is shown in Figure 3. After taking $0.5 \mathrm{~g}$ of the prepared samples, $0.5 \mathrm{ml}$ of purified water, $3 \mathrm{ml}$ of "Coomassie Brilliant Blue G250 " dye solution and $4 \mathrm{ml}$ of phosphate buffer solution were added, and the absorbance values were measured at $595 \mathrm{~nm}$ wavelength. The amount of protein in 1 gram of fresh leaf was calculated as mg. 


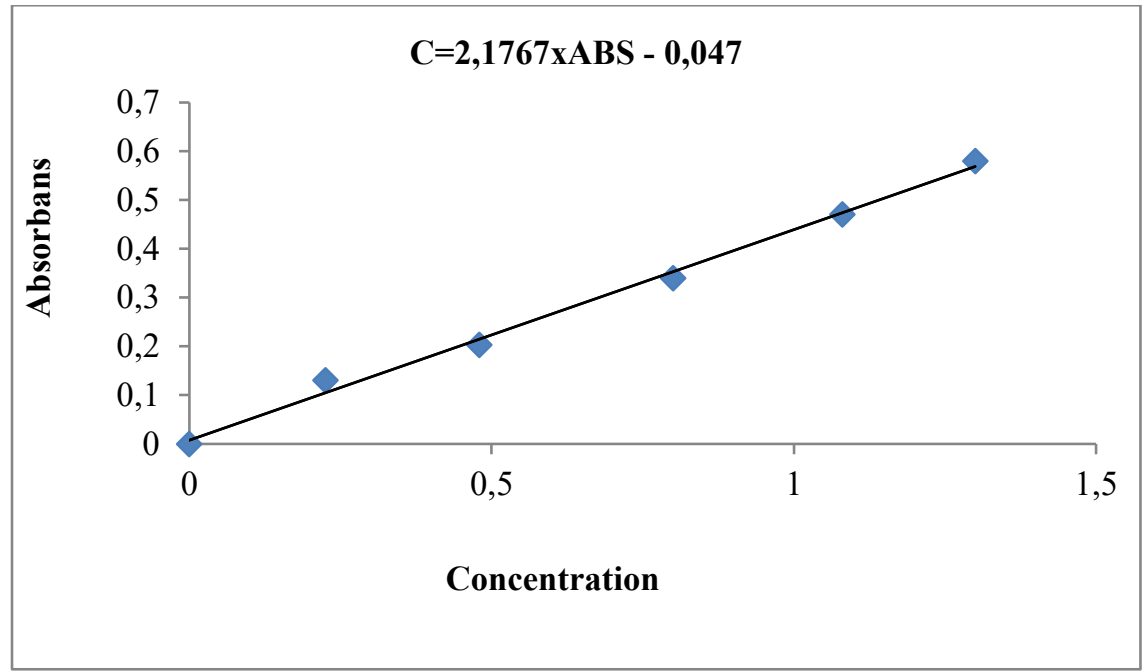

Figure 3.UV standard curve for protein, $(595 \mathrm{~nm})$

The dry matter amount was determined on specimens taken from leaves and trunks. These samples were weighed immediately after being collected and their wet weights were found. They were then placed in a petri dish and dried at $80{ }^{\circ} \mathrm{C}$ in an incubator until they reached constant weight, and their dry weights were determined. Based on the difference between the values obtained, the quantities of dry matter in $1 \mathrm{~g}$ of fresh-tissue were determined.

\section{Results and Discussion}

The effects of dusts emitted by a cement factory on various plant species were examined in this study. For this purpose, chlorophyll a, chlorophyll b and total chlorophyll, carbohydrate, dry matter and soluble protein parameters were evaluated in plant samples.

Plants are greatly affected by the ambient conditions they are in. As a result, changes occur in plant organelles and metabolic products (Gond, DePury, Veroustraete \& Ceulemans, 2012; Kurtar, 2012). As it is known, chloroplasts, one of the most important organelles that enable plants to grow and develop, play an active role in the synthesis of organic materials. For this reason, chlorophyll a, chlorophyll $\mathrm{b}$ and total chlorophyll levels of plant samples taken from polluted areas were compared to plant samples taken from unpolluted areas. The results are given in Table 1.

Table 1. The amount of chlorophyll

\begin{tabular}{|c|c|c|c|c|c|c|c|c|c|}
\hline \multirow{2}{*}{$\begin{array}{c}\text { Plant } \\
\text { Species }\end{array}$} & \multirow{2}{*}{ Sampling } & Measured & \multicolumn{5}{|c|}{ The amount of chlorophyll $(\mathrm{mg} / \mathrm{g})$} & \multirow{2}{*}{$\begin{array}{c}\text { Aver } \\
\text { g. }\end{array}$} & \multirow{2}{*}{$\begin{array}{c}\% \% \\
\text { Variation }\end{array}$} \\
\hline & & Parameters & I & II & III & IV & $\mathrm{V}$ & & \\
\hline \multirow{6}{*}{$\frac{\Xi}{\text { 되 }}$} & \multirow{3}{*}{ Dustless } & Chlorophyll a & 0,836 & 0,726 & 0,792 & 0,939 & 1,006 & 0,860 & \multirow{6}{*}{29,9} \\
\hline & & Chlorophyll b & 0,450 & 0,445 & 0,465 & 0,463 & 0,643 & 0,493 & \\
\hline & & Total Chlorophyll & 1,286 & 1,172 & 1,256 & 1,402 & 1,649 & 1,353 & \\
\hline & \multirow{3}{*}{ Dusty } & Chlorophyll a & 0,466 & 0,418 & 0,681 & 0,625 & 0,703 & 0,579 & \\
\hline & & Chlorophyll b & 0,279 & 0,290 & 0,425 & 0,364 & 0,489 & 0,369 & \\
\hline & & Total Chlorophyll & 0,745 & 0,708 & 1,105 & 0,989 & 1,192 & 0,948 & \\
\hline \multirow{6}{*}{$\frac{0}{\stackrel{0}{E}}$} & \multirow{3}{*}{ Dustless } & Chlorophyll a & 0,787 & 0,752 & 0,733 & 0,875 & 0,946 & 0,818 & \multirow{6}{*}{19,3} \\
\hline & & Chlorophyll b & 0,424 & 0,354 & 0,449 & 0,412 & 0,509 & 0,430 & \\
\hline & & Total Chlorophyll & 1,210 & 1,106 & 1,182 & 1,286 & 1,455 & 1,248 & \\
\hline & \multirow{3}{*}{ Dusty } & Chlorophyll a & 0,588 & 0,681 & 0,592 & 0,545 & 0,602 & 0,602 & \\
\hline & & Chlorophyll b & 0,392 & 0,454 & 0,411 & 0,368 & 0,401 & 0,405 & \\
\hline & & Total Chlorophyll & 0,980 & 1,135 & 1,002 & 0,914 & 1,003 & 1,007 & \\
\hline \multirow{6}{*}{ 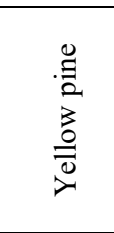 } & \multirow{3}{*}{ Dustless } & Chlorophyll a & 0,683 & 0,629 & 0,673 & 0,666 & 0,722 & 0,675 & \multirow{6}{*}{8,8} \\
\hline & & Chlorophyll b & 0,455 & 0,420 & 0,468 & 0,463 & 0,481 & 0,457 & \\
\hline & & Total Chlorophyll & 1,138 & 1,049 & 1,142 & 1,129 & 1,203 & 1,132 & \\
\hline & \multirow{3}{*}{ Dusty } & Chlorophyll a & 0,563 & 0,613 & 0,619 & 0,630 & 0,628 & 0,617 & \\
\hline & & Chlorophyll b & 0,391 & 0,426 & 0,396 & 0,420 & 0,442 & 0,415 & \\
\hline & & Total Chlorophyll & 0,954 & 1,039 & 1,015 & 1,051 & 1,100 & 1,032 & \\
\hline
\end{tabular}


As seen in Table 1, the chlorophyll a and chlorophyll $\mathrm{b}$ analysis of fresh leaf tissues revealed significant reductions $(\mathrm{p}<0.01)$ in total chlorophyll levels of plants growing in areas affected by dust in comparison to plant samples taken from dust-free areas. In particular, it was seen that the decrease in total chlorophyll levels was very significant in maple $(\mathrm{p}<0.005)$. The mean chlorophyll values determined for elm, maple and yellow pine samples obtained from unpolluted areas were determined to be $1.353,1.248$ and 1.032 , respectively, whereas these values for the same plants taken from polluted areas were $0.948,1.007$ and 1.032 , respectively. The decreases in chlorophyll contents were also found to be $29.9 \%, 19.3 \%$ and $8.8 \%$, respectively. Similar findings were obtained in studies on sunflower (Borka, 1980), wheat (Singh \& Rao 1981), maize and poplar (Cireli, 1975). Additionally, Katırcıoğlu \& İren (1988) found a 29\% reduction in chlorophyll in bean and apple plants affected by dust emissions. Czaja (1966) and Lerman (1972) showed that a decrease in chlorophyll

Table 2. The amount of carbohydrate levels directly affected photosynthesis, and hence plant growth and development, negatively. They proved in various experiments that, as accumulated dusts turned into an alkaline solution, they progressed from the epidermis to palisade and sponge parenchyma, damaging the chloroplasts and the tissues (Katırcioğlu \& İren, 1984). Various studies have been carried out on the effects of cement dusts, which cause a decrease in chlorophyll levels and thus photosynthesis rate, and reduce dry matter and carbohydrate amounts in tissues to elicit adverse effects on plant growth and development.

Carbohydrates, which are among the metabolic products in plants, are found in various forms. The carbohydrates subject to this study were hexoses and pentoses, which are the most common monosaccharides in plants. In the experiments examining the changes in carbohydrate levels in plants, samples were obtained from polluted areas affected by cement dusts, and unpolluted areas. Analyses of hexose, pentose and total carbohydrate levels were performed on these samples and the results are shown in Table 2.

\begin{tabular}{|c|c|c|c|c|c|c|c|c|c|}
\hline \multirow{2}{*}{$\begin{array}{l}\text { Plant } \\
\text { Species }\end{array}$} & \multirow{2}{*}{ Sampling } & \multirow{2}{*}{ Measured Parameters } & \multicolumn{5}{|c|}{ The amount of carbohydrate $(\mathrm{mg} / \mathrm{g})$} & \multirow{2}{*}{ Averg } & \multirow{2}{*}{$\begin{array}{c}\% \\
\text { Variation }\end{array}$} \\
\hline & & & $\mathrm{I}$ & II & III & IV & $\mathrm{V}$ & & \\
\hline \multirow{6}{*}{$\frac{\Xi}{\square I}$} & \multirow{3}{*}{ Dustless } & Hexose & 0,777 & 0,667 & 0,746 & 0,612 & 0,706 & 0,702 & \multirow{6}{*}{25} \\
\hline & & Pentose & 0,763 & 0,530 & 0,469 & 0,721 & 0,735 & 0,644 & \\
\hline & & Total carbohydrate & 1,540 & 1,197 & 1,216 & 1,333 & 1,441 & 1,345 & \\
\hline & \multirow{3}{*}{ Dusty } & Hexose & 0,738 & 0,531 & 0,645 & 0,548 & 0,468 & 0,586 & \\
\hline & & Pentose & 0,437 & 0,200 & 0,240 & 0,711 & 0,535 & 0,425 & \\
\hline & & Total carbohydrate & 1,175 & 0,731 & 0,885 & 1,259 & 1,003 & 1,010 & \\
\hline \multirow{6}{*}{$\frac{\frac{0}{2}}{\frac{\pi}{\Sigma}}$} & \multirow{3}{*}{ Dustless } & Hexose & 0,602 & 0,510 & 0,835 & 0,558 & 0,561 & 0,613 & \multirow{6}{*}{23} \\
\hline & & Pentose & 0,455 & 0,470 & 0,669 & 0,430 & 0,467 & 0,498 & \\
\hline & & Total carbohydrate & 1,057 & 0,980 & 1,504 & 0,988 & 1,028 & 1,111 & \\
\hline & \multirow{3}{*}{ Dusty } & Hexose & 0,488 & 0,455 & 0,537 & 0,355 & 0,460 & 0,459 & \\
\hline & & Pentose & 0,372 & 0,371 & 0,485 & 0,342 & 0,406 & 0,395 & \\
\hline & & Total carbohydrate & 0,860 & 0,826 & 1,022 & 0,697 & 0,866 & 0,854 & \\
\hline \multirow{6}{*}{ 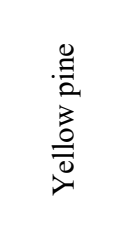 } & \multirow{3}{*}{ Dustless } & Hexose & 0,684 & 0,555 & 0,579 & 0,584 & 0,631 & 0,607 & \multirow{6}{*}{12} \\
\hline & & Pentose & 0,288 & 0,306 & 0,363 & 0,371 & 0,431 & 0,352 & \\
\hline & & Total carbohydrate & 0,972 & 0,861 & 0,942 & 0,955 & 1,062 & 0,958 & \\
\hline & \multirow{3}{*}{ Dusty } & Hexose & 0,454 & 0,372 & 0,421 & 0,469 & 0,463 & 0,436 & \\
\hline & & Pentose & 0,384 & 0,356 & 0,418 & 0,431 & 0,440 & 0,406 & \\
\hline & & Total carbohydrate & 0,838 & 0,728 & 0,838 & 0,900 & 0,903 & 0,841 & \\
\hline
\end{tabular}

Table 2 shows that the mean carbohydrate amounts in plants collected from cleaner areas where dust emissions were not effective were $1.345,1.111$ and $0.958 \mathrm{mg} / \mathrm{g}$ for elm, maple and yellow pine, respectively. For samples collected from areas affected by cement dust, the mean carbohydrate levels were $1.010,0.854$ and 0.841 , for elm, maple and yellow pine, with decreases of $25 \%, 23 \%$ and $12 \%$, respectively. At the same time, significant reductions in carbohydrate amounts for elm and yellow pine were determined at locations where dust emissions were effective $(p<0.01)$, but no significant change was observed for maple. Some researchers obtained similar findings in their 
studies. A decrease was reported in starch and sugar levels due to increased dust levels by Lerman (1972) in peas, by Anda (1986) in corn, and by Katırcioğlu \& İrem (1988) in beans and apples. When Table 2 is examined, it is seen that in the plants growing in polluted areas, there were significant reductions in comparison to plants growing in unpolluted areas. The significance level for dry matter in elm and maple leaves was $\mathrm{p}<0.01$, while the significance level in the trunks was $\mathrm{p}<0.005$.

Amount of dry matter was determined on the samples taken from leaves and trunks in the plants selected for use in this study. The results are shown in Table 3 .

Table 3.The amount of dry matter

\begin{tabular}{|c|c|c|c|c|c|c|c|c|c|}
\hline \multirow{2}{*}{$\begin{array}{c}\text { Plant } \\
\text { Species }\end{array}$} & \multicolumn{2}{|c|}{ Sampling } & \multicolumn{5}{|c|}{ The amount of dry matter $(\mathrm{mg} / \mathrm{g})$} & \multirow[t]{2}{*}{ Averg. } & \multirow{2}{*}{$\begin{array}{c}\% \% \\
\text { Variation }\end{array}$} \\
\hline & & & I & II & III & IV & $\mathrm{V}$ & & \\
\hline \multirow{4}{*}{$\frac{\Xi}{\square}$} & \multirow{2}{*}{ Leaf } & Dustless & 0,52 & 0,42 & 0,41 & 0,37 & 0,48 & 0,44 & \multirow{2}{*}{20,5} \\
\hline & & Dusty & 0,37 & 0,36 & 0,31 & 0,32 & 0,39 & 0,35 & \\
\hline & \multirow{2}{*}{ Bole } & Dustless & 0,62 & 0,75 & 0,67 & 0,67 & 0,68 & 0,68 & \multirow[t]{2}{*}{19,18} \\
\hline & & Dusty & 0,56 & 0,60 & 0,53 & 0,54 & 0,54 & 0,55 & \\
\hline \multirow{4}{*}{$\frac{0}{\frac{0}{a}}$} & \multirow{2}{*}{ Leaf } & Dustless & 0,36 & 0,40 & 0,41 & 0,39 & 0,33 & 0,38 & \multirow{2}{*}{21} \\
\hline & & Dusty & 0,34 & 0,36 & 0,32 & 0,21 & 0,26 & 0,30 & \\
\hline & \multirow{2}{*}{ Bole } & Dustless & 0,55 & 0,60 & 0,54 & 0,57 & 0,62 & 0,58 & \multirow{2}{*}{13,80} \\
\hline & & Dusty & 0,52 & 0,50 & 0,45 & 0,44 & 0,58 & 0,50 & \\
\hline \multirow{4}{*}{ 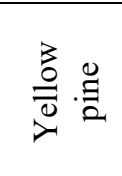 } & \multirow{2}{*}{ Leaf } & Dustless & 0,51 & 0,49 & 0,48 & 0,45 & 0,50 & 0,48 & \multirow{2}{*}{10,42} \\
\hline & & Dusty & 0,44 & 0,47 & 0,44 & 0,40 & 0,42 & 0,43 & \\
\hline & \multirow{2}{*}{ Bole } & Dustless & 0,55 & 0,59 & 0,61 & 0,64 & 0,57 & 0,59 & \multirow{2}{*}{10,17} \\
\hline & & Dusty & 0,55 & 0,53 & 0,48 & 0,57 & 0,51 & 0,53 & \\
\hline
\end{tabular}

Table 3 shows that the amount of dry matter was lower in areas affected by dust in comparison to dust-free areas. The decrease in the amount of dry matter was on different levels for leaf and trunk tissues. Reductions in the amount of dry matter in the leaf tissue were found to be insignificant in maple, while a significant decrease was observed for elm and yellow pine $(p<0.01)$. In trunk tissues, a highly significant decrease was observed in elm $(p<0.005)$, while no significant change was observed in maple and yellow pine. Similar results were obtained in other studies on the effects of pollutants on the amount of dry matter in plants. Various studies have shown that the amount of dry matter in olive trees decreased considerably (Sheik et al., 1976), and decreases were observed in the amount of dry matter in corn plants (Anda, 1986). Cireli (1975) reported that dry matter production decreased in various plants under the effect of pollutants, and this effect occurred due to inhibition of light available for photosynthesis in plants by dust.

Another important metabolic product in living organisms is protein (Yadeghari, Heidari \& Carapetian, 2008). Proteins constitute approximately $50-80 \%$ of the dry weight of cells. Most of the substances that create seeds and other plant parts are in protein form. Additionally, all enzymes are in protein form (Akman, 1980). Separate assessments were performed for dusty and dust-free regions to analyze soluble protein levels, and the results are given in Table 4 .

Table 4.Amounts of soluble protein

\begin{tabular}{|c|c|c|c|c|c|c|c|}
\hline \multirow{2}{*}{$\begin{array}{c}\text { Plant } \\
\text { Species }\end{array}$} & \multirow{2}{*}{ Sampling } & \multicolumn{5}{|c|}{ Amounts of soluble protein $(\mathrm{mg} / \mathrm{g})$} & \multirow{2}{*}{ Averg } \\
\hline & & $\mathrm{I}$ & II & III & IV & $\mathrm{V}$ & \\
\hline \multirow{2}{*}{ Elm } & Dustless & 2,925 & 3,139 & 3,070 & 2,967 & 2,366 & 2,893 \\
\hline & Dusty & 2,143 & 2,186 & 2,514 & 2,235 & 2,322 & 2,280 \\
\hline \multirow{2}{*}{ Maple } & Dustless & 2,152 & 1,972 & 1,714 & 2,000 & 2,033 & 1,974 \\
\hline & Dusty & 2,033 & 1,539 & 1,368 & 1,520 & 1,421 & 1,576 \\
\hline \multirow{2}{*}{ Yellow pine } & Dustless & 2,014 & 2,343 & 2,175 & 2,273 & 2,754 & 2,312 \\
\hline & Dusty & 2,004 & 1,847 & 1,672 & 1,795 & 1,977 & 1,853 \\
\hline
\end{tabular}


When Table 4 is examined, a decrease may be seen in the amount of protein in the plants growing in highly polluted areas. This decrease was significant in yellow pine $(p<0.01)$, and elm $(p<0.005)$. Although no significant decrease was found in maple, a $20 \%$ decrease was observed.

\section{Conclusions}

In conclusion, chlorophyll a and chlorophyll $\mathrm{b}$ analyses of fresh leaf tissues revealed that total chlorophyll content of the plants growing in areas affected by dust showed a significant decrease in comparison to the plant samples obtained from dust-free areas. In particular, it was seen that chlorophyll levels decreased considerably in maple. This shows that maple is more sensitive to dust than the other plants.

According to the results of the carbohydrate analysis, it was found that carbohydrate levels significantly decreased in elm and yellow pine in the samples obtained from the polluted area in comparison to the samples collected from the unpolluted area. The amount of dry matter, one of the benchmarks for plant growth and development, was also found to decrease in the samples collected from the polluted area in comparison to the samples collected from the unpolluted area. Decreases in the amount of dry matter in the leaves were significant in elm and yellow pine, whereas in the trunk region, a significant decrease was observed only in elm.

Soluble protein amounts were also compared among the plant samples collected from clean and polluted areas. Except for elm, no significant reductions were found in protein levels. It was found that dust accumulating on the plants formed a covering layer on the leaves, preventing photosynthesis, which is highly important for plants, as well as reacting with moisture and transforming into an alkaline solution. Thus, dust emissions damage chloroplasts in the leaves, thereby reducing chlorophyll levels and indirectly slowing the photosynthetic metabolism.

Our findings indicate that the dust emissions of the studied cement factory had an adverse effect on meadows and pasture areas, as well as other vegetation. For this reason, in order to protect the nature, it has become necessary to consider environmental impact assessments seriously before establishing facilities such as cement factories.

\section{References}

Anda, A. (1986). Effect of cement -kiln dust on the radiation balance and yelds of plant, Environmental Pollution, 40, 249-256.

Akman, Y. (1980). Botanik. Ankara Üniversitesi, Eczacılık Fakültesi Yayınları, 144-145.

Anonim (1983). Türkiye'nin çevre sorunlarl. Önder Matbaası. Ankara: Türkiye Çevre Sorunları Vakfi Yayını.

Bayhan, Y. \& K. (2016). Çimento toz emisyonlarının bazı bitkilerin yapı ve metabolitlerine etkileri, Kastamonu University Journal of Forestry Faculty, 16 (1), 147-152.

Bayhan, Y. K., Yapici, S., Kocaman, B., Nuhoglu, A. \& Cakici, A. (2002). The Effects of Cement Dust on Some Soil Characteristics, Fresenius Environmental Bulletin, 11(11), 1030- 1033.

Berges, L., Chevalier, R., Dumas, Y., Franc, A. \& Gilbert, J.M. (2005). Sessile oak (Quercus petraea Liebl.) site index variations in relation to climate, topography and soil in even-aged high-forest stands in northern France. Annals of Forest Science, 62 (5), 391-402.

Borka, G. (1980). The Effect of Cement Dust Pollution on Growth and Metabolism of Helianthus Annus. Environmental Pollution, 40, 249-256.

Bilen, S. (2010). Effect of cement dust pollution on microbial properties and enzyme activities in cultivated and no-till soils. African Journal of Microbiolgy Research, 4(2), 2418- 2425.

Bradford, M.M. (1976). A rapid and sensitive method for the quantition of microgram quantities of protein utilizing the principle of protein-dye brinding. Analytical Biochemistry, 72248.

Brandt, C.J. \& Rhoades, R.W. (1972). Effects of limestones dust accumulation on composition of a forest community, Environmental Pollution, (3), 217-225.

Brandt, C.J. \& Rhoades, R.W. (1973). Effects of limestone dust Accumulation on Lateral Growth of forest trees, Environmental Pollution, (4), 207-213.

Cireli, B. (1975). Endüstriyel baca gazlarının nif dağ1 vejetasyonuna etkileri, Bitki, 2, 2(2), 2326.

Czaja, W. (1966). The effect of dust upon plants, Angewandte Botanic, 40, 106-120.

Çetin, M. (2016). Peyzaj çalışmalarında kullanılan bazı bitkilerde klorofil miktarının değişimi, Kastamonu University Journal of Forestry Faculty. 16(1), 239-245. 
Düzgüneş, O. (1963). Bilimsel araştırmalarda istatistik prensipleri ve metodlart. Ankara Ünversitesi Ziraat Fakültesi Yayını.

Gond, V., DePury, D.G.G., Veroustraete, F. \& Ceulemans, R. (2012). Seasonal variations in leaf area index, leaf chlorophyll, and water content; scaling-up to estimate Fapar and carbon balance in a multilayer, multispecies temperate forest, Tree Physiology, 19(10), 673-679.

Kaçar, B., (1972). Bitki ve toprağın kimyasal analizleri. Ankara Ünversitesi Ziraat Fakültesi Yayını No. 453.

Kadıŏlu, A. (2004). Bitki fizyolojisi. Trabzon: Lokman Yayın, 453.

Karpuzcu, M. (1988). Çevre Mühendisliğine Giriş. İ.T.Ü. İnşaat Fakültesi Matbaası İstanbul, s 146.

Katırcıŏlu, Y.Z. \& İren, S. (1984). Çimento Firın Tozlarinin Elma ve Fasulye Yapraklarının Anatomisine ve Elma Sürgünlerinin Morfolojisine Etkileri, TUBITAK Ulusal Çevre Sempozyomu, Adana.

Katırcioğlu, Y.Z. \& İren, S. (1988). Çimento Firın Tozlarının Elma ve Fasulye Bitkilerinin Fotosentezine Olan Olumsuz Etkileri, Çevre, 6, 31-44.

Kurtar, E.S. (2012). Sera Ekolojisi Ders Notlart. Ondokuz Mayıs Üniversitesi, Bafra Meslek Yüksek Okulu, p.72, Samsun.

Lafraguta, C., Garcia-Criado, B., Arranz, A. \& Vazquez-de-Aldana, BR. (2014). Germination of medicago sativa is inhibited by soluble compounds in cement dust. Environmental Science and Pollution Research, 22(2), 128512901

Lerman, S. (1972). Cement-kiln dust and the bean plant in-depth investigations into plant morphology, physcology and patology, Ph. D. Dissertation, University of California, Riverside.

Lux, H. (1974). Contamination of the top soil in pinus sylvestris stands by basic duste of industrial origin. Wissenschoffliche Zeatschrift der Technischen Universital Dresden (23), 915-920, 1974.

Norris, J.R. \& Ribbons, D.W. (1971). Methods in Microbiology, Vol. 5 B, 468-474, London.

Öner, N., Ayan, S., Sivacioğlu, A. \& İmal, B. (2007). Kent ormancilığ ve kent ormanlarının çevresel etkileri. kastamonu üniversitesi
Orman Fakültesi Dergisi, Cilt:7 No:2. 13032399.

Rhoads, A. F. (1976), forest species show a delayed response to cement dust in the soil. I Arbori. 2, 197-199 Singh S.N., Roa D.N., 1981 Certain responses of wheat plants to cement dust pollution. Environmental Pollution Series A, Ecological and Biological, 24(1), Pages 75-81.

Sağlam, S. \& Elvan, O.D. (2017). Kent ormanlarının Türkiye'deki gelişimi ve hukuki durumu. Kastamonu Universitesi Orman Fakültesi Dergisi, 17(4), 669-681.

Sariyildiz, T., Savac1, G. \& Maral, Z. (2009). Effect of different land uses (Mature and young fir stands pasture and agriculture sites) on soil organic carbon and total nitrogen stock capacity in Kastamonu Region. Kastamonu University Journal of Forestry Faculty, 17 (1), 132-142.

Sariyildiz, T. \& Küçük, M. (2009). Influence of slope position, stand type and rhododendron (Rhododendron ponticum) on litter decomposition rates of oriental beech (Fagus orientalis Lipsky.) and spruce (Picea orientalis (L.) Link). European Journal of Forest Research. 128, 351-360. doi:10. 1007/s10342009-0270.

Singh, S.N. \& Rao, D. N. (1981). Certain response of wheat plants to cement dust pollution. Environment Pollution, A, 24, 75.

Sheikh, H.K., Öztürk, M. \& Vardar, Y. (1976). Field studies of the effects of cement dust on the growth and yield of olive trees in Turkey, Environmental Conservation, 3(2), 117-121.

Turfan, N., Savac1, G. \& Sarıyıldız, T. (2016). Uludağ göknarı ve sarıçam ibrelerinin bazı kimyasal bileşiklerinin meşcere yaşına ve bazı toprak özelliklerine bağlı olarak değişimi, Kastamonu University Journal of Forestry Faculty, 16 (2), 583-598.

Voran, V.P. (1984). Pollution of grey forest soils with alkali and alkaline-earth metals in an area affected by cement dust emissions. Lesovodstvo Agrolesomelioratsiya, 68, 27-31.

Yadeghari L.Z., Heidari, R. \& Carapetian, J. (2008). The influence of cold acclimation on proline, malondialdeyde (MAD), total protein and pigments contents in soybean (Glycine max) seedlings. Research Journal of Biological Sciences, 3(1):74-79. 